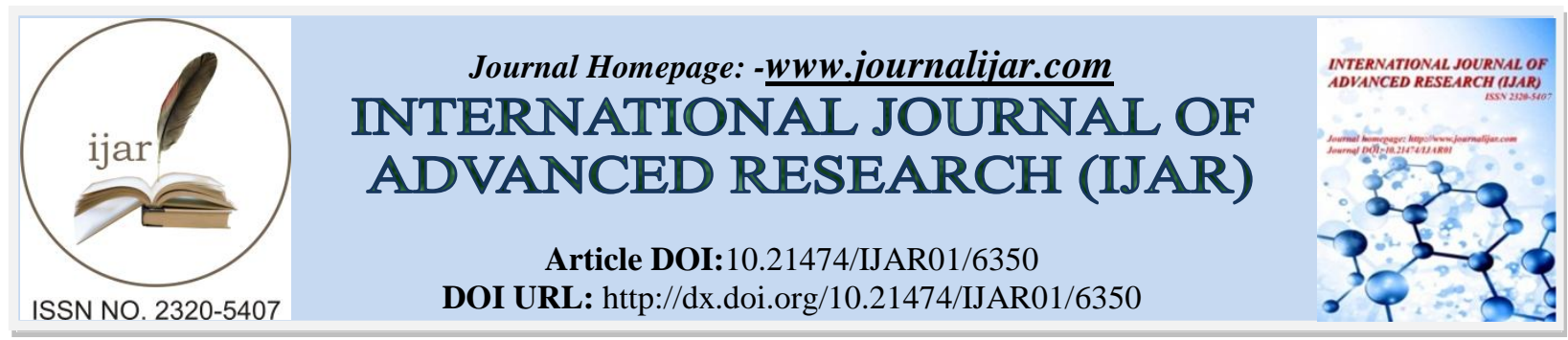

RESEARCH ARTICLE

EMPLOYEES' CITIZENSHIP BEHAVIOR ON MANAGING ENVIRONMENT: ITS RELATION TO JOB DESCRIPTION, LEADER BEHAVIOR AND PERSONALITY.

Rina Lusiani

Manuscript Info

Manuscript History

Received: 19 November 2017

Final Accepted: 21 December 2017

Published: January 2018

Key words:-

Job Description, Leader Behavior, Personality, Citizenship Behavior On Managing The Environment.

\begin{abstract}
This research was aimed at finding out whether there was a relationship between job description, leader behaviorand personality with employees' citizenship behavior on managing the environment. A correlational study was used by involving 150 employees of industrial park as a sample. There were four instruments which measured citizenship behavior on managing the environment (rel. .939), job description (rel. .934), leader behavior (rel. .926), and personality (rel. .971). Data was analyzed by regression and correlation. Results revealed that there was positive and significant correlation among those variables, even though it was controlled by second-order correlation, it was still significant among them. Therefore, it could be concluded that if citizenship behavior on managing the environment would be improved, then job description, leader behavior and personality should be taken into consideration.
\end{abstract}

Copy Right, IJAR, 2018,. All rights reserved.

\title{
Introduction:-
}

Behavior in managing the environment is needed in order to improve employee behavior regarding environmental impacts that can contribute positively and negatively in achieving organizational or company goals. Behavior in managing the environment is based on the response of environmental problems to the management such as how management actions in the process of using natural resources efficiently and effectively. The company itself is often faced with many priorities to do, on the one hand for business competition and on the other hand for attention to the natural environment.

The previous research as a reference of research conducted by researchers is by Mukherjee danGhosh (2014: 108), over the past few decades, India has seen the rise of corporate social responsibility (CSR) among corporation. In themiddle of economic and social upheaval and from the immense pressure from environmentally conscious consumers,government and environment activists, Indian organizations are increasingly rectifying their CSR strategies in order toexpress their responsible nature.Different studies have been conducted CSR and environmental sustainability whereby showing different kinds of relationshiphuman behavior and CSR practices. Research suggested how organizations are positively inclined to protect the presentwhile fulfilling the need but without compromising the needs of future generation. This paper investigates and reviews literature regarding the mentioned problem which is based on secondary data. The paperexplores the effect of environmental CSR on companies' sustainability. The main objective of this paper is to find out thestrategies companies are framing regarding environmental sustainability and incorporating them into their CSR activities.Conclusion and recommendation is made on what strategies companies should be following to sustain their green image. 
Furthermore, research by Bakker, Tims and Derks (2012: 1360-1361), states that some studies have revealed positive personalities in employees showing good job performance as well. Therefore, management can affect the work of employees and resources generated. It is important for employees to demonstrate proactive behavior and optimize the work environment of employees. Research conducted by Takashi Mino and Keisuke Hanaki (2013: 1923), that the development of environmental leadership can holistically face the existing environmental problems. Environmental leaders promote the sustainability of environmental issues to protect the natural environment in decision-making and action processes. The transformational leader encourages his followers to act for a specific purpose that represents the values and motivations between leaders and followers. Thus, the transformational-style leadership variables affect the environmental performance of the organization.

Research conducted by Olivier Boiral, Charles Baron and Olen Gunnlaugson (2014: 1-34), that successful implementation of the practice environment (ie, implementation of sustainability policies, pollution prevention measures, industrial ecological promotion, environmental training programs) execution of active environmental commitment from top managers. This is based on an institution or organization that cares about the environment around it is highly dependent on the extent to which leaders have commitment and leadership in positioning themselves as top managers in the implementation of management functions (management functions ), so that it can improve the function of organizational structure.

According to Robertson and Barling (2013: 176-177), although environmental leadership is generally regarded as a prerequisite for environmental improvement in greening institutions, few studies focus on management systems and the ability to influence sustainability commitments. So in improving employee's environmental performance, leaders need to be oriented toward sustainable environmental awareness. Integrative model of organizational behavior, according to Colquitt et al., 2011), leaders and employees as individuals can be assessed from individual achievements (individual outcomes) of job performance or behavior that contributes good or bad and organizational commitment performance) is strong or weak individual desires in the organization or institution.

There are several factors affecting individual achievement (individual outcomes) within an organization. Individual characteristic factors are personality and group mechanisms, one of which is leadership behaviors. Based on perceptions, an environmentally based company should be able to improve wise behavior in managing the environment and minimize negative impacts on the environment. Where the influence of positive leadership and personality is what can lead to a positive environmental performance.

Based on some of the International Journal mentioned above, the novelty in this research on behavior in managing the environment which is related to job description, leader behavior and personality. Researchers interested in conducting research on the relationship between job description, leader behavior and personality with citizenship behavior on managing the environment. Where the influence of positive leadership and personality is what can lead to positive environmental performance. Based on some of the International Journal mentioned above, novelty of this research the citizenship behavior on managing the environment associated with job description, leader behavior and personality.

Pervin and Oliver (1997: 21) suggests that, one's behavior can be maintained or maintained for long periods of time. Rue and Byars (2006: 6) argue that, organizing is grouping activities, assigning activities an providing the authority necessary to carry out theactivities. In simple terms according to Luthan (2008: 150), behavior in managing the environment based on organizational citizenship behavior can be interpreted as an attitude or organizational behavior that is aligned and serves for the benefit of the organization.

Some experts defined organizational citizenship behavior defines OCB as individual behavior that is discretionary, not directly or explicitly recognized by the formal reward system, and that in the aggregate promotes the effective functionaing of the organization. The personality foundation for these organization citizenship behaviors reflects the employee's predispositional traits to the cooperative, helpful, caring, and conscientious. The attitudinal foundation indicates that employee engage in OCBs in order to reciprocate the actions of their oragnizations.

Further explained byLuthan (2008: 151) that the behavior of organizational personnel is in some form, but can be classified as, OCBs can take many forms, but the major ones could be summarized as: 1) altruism (e.g., helping out when a coworker is not feeling well), 2) conscientiousness (e.g., staying late to finish a project), 3) civic virtue (e.g., volunteering for a community program to represent the firm), 4) sportsmanship (e.g., sharing failure of a team 
project taht would have been success full by following the member's advice), 5) courtesy (e.g., being understanding and empathetic even when provoked. This suggestion implies that for every member of the organization must build an attitude of self-interest, build a high awareness, social, honest about everything, and courtesy. If some of these attitudes woke up would certainly raise the life of the organization. This suggestion implies that for every member of the organization must build an attitude of self-interest, build a high awareness, social, honest about everything, and courtesy. If some of these attitudes woke up would certainly raise the life of the organization. From some of the description and analysis of the concept above, the synthesis of wise behavior in managing the environment is an action done by someone who contributes in managing the environment for organizational goals through dimension helping, sportsmanship, loyalty, organizational compliance, individual initiative, civic virtue, danself development.

According to Colquit, Lepine, and Wesson (2011: 527), Job description was stated that how jobs and tasks are divided and coordinated between individuals and groups within the company. One way of getting a feel for an organization's structure is by looking at an organizational chart. An organizational chart is a drawing that represents every job in the organization and the formal reporting relationships between those jobs. It helps organizational members and outsiders understand and comprehend how work is structures within the company. While Ivancevich, Konopaske, and Michael.T (2011: 22) define the division of labor as follows, Job description is the formal pattern of activities and interrelationships among the various subunits of the organization. Viewing an organization chart on a piece of paper or framed on a wall, one sees only a configuration of positions, job duties, and lines of authority among the parts of an organization. Job description can be far more complex than that. Based on the above description, the synthesis of the division of labor is the activity of employees in the division of tasks between individuals and groups within the company include the dimensions of work specialization, control range, command line, formalities, delegates (centralization and decentralization) to preserve the environment in achieving green industry.

On the other occasion, Yukl (2010: 22) stated that leadership is in terms of an influence process that occurs naturally within a social system and is diffused among the members. Leadership is the process of influencing a person or group of people in a group or an organization. As Colquitt, et.al. (2011) defined that leadership as use power and influence to direct the activities of followers toward goal achievement". Leadership is the use of power and influence directing subordinate activities in achieving goals. Robbins and Judge (2013: 368-371) defined that leadership is the ability to influence a group of people in achieving a vision or set of goals. In the Trait theories of leadership, one's leadership is seen in one's quality and character. Whereas in behavioral theory of leadership, subordinates see the leader from the aspect of initiating structure is how far the leader explains the plan and the role of the subordinate and the attention (consideration), that is how far the leader builds friendship relationship with the staff to trust each other (mutual trust), attention to the ideas of subordinates (respect for employee's). From some research, $66 \%$ of staff are motivated by the attention of the leadership.So, leader behavior is the action of a leader who is assessed by employees in managing the environment to achieve corporate goals that have a positive impact through the dimensions of consideration and initiating structure.

Pervin (1996, in Rhodewalt (2008: 1), stated that personality is the complex organization of cognitions, affects and behaviors that gives direction and pattrern (coherence) to the persons life Personality consists of both structures and processes and reflects both nature (genes) and nurture experience. Personality is a complex cognitive organization that influences behavior to give direction and pattern of one's life, personality consists of structure and process, both natural (gen) and experience. So personality is a complex knowledge that can affect behavior on a particular purpose. Colquitt, LePine and Wesson (2009: 293) in The Big Five personality model explains, there are five factors underlying human personality that is conscientiousness, agreeableness, neuroticism, openness, and extraversion. From some of the above explanations, the synthesis of personality is one's traits in responding, reacting, and interacting relatively stable with others and its environment includes conscientiousness, agreeableness, neuroticism, openness, extraversion to achieve organizational goals. Based on the description, the researcher is interested to conduct research on the relationship between job description, leader behavior and personality with behavior in managing environment, correlational study on employees in Krakatau Steel Company Cilegon, Banten year 2016.

\section{Research Methodology:-}

The purpose of this research was to find a relationship between job description, leader behavior, and personality with citizenship behavior on managing the environment. A correlational study was used by selecting randomly 150 employees as sample. There were four instruments to messurecitizenship behavior on managing the environment (rel .939), job description (rel .934), leader behavior (rel. 926), and personality (rel .971). 
Data was calculatedby descriptive and inferential statistics. And then, it was analyzed by simple and multiple regression, followed by finding out its second-order correlation and verified by t-test.

\section{Research Findings and Discussion:-}

The relationship between job description with citizenship behavior on managing the environment could be seen in the regression model with regression coefficients $b=.442$ and $a=77.960$.

Table 1:-ANOVA Table for Regression Model of $\hat{Y}=77.960+.442 X_{1}$

\begin{tabular}{|l|c|c|c|c|c|c|}
\hline \multicolumn{1}{|c|}{$\begin{array}{c}\text { Source of } \\
\text { Variances }\end{array}$} & $\begin{array}{c}\text { Degrees of } \\
\text { Freedom (DF) }\end{array}$ & $\begin{array}{c}\text { Sum of } \\
\text { Square } \\
\text { (SS) }\end{array}$ & $\begin{array}{c}\text { Means } \\
\text { Square } \\
\text { (MS) }\end{array}$ & \multicolumn{2}{|c|}{$\mathrm{F}_{\text {cal }}$} & \multicolumn{2}{c|}{$\mathrm{F}_{\text {table }}$} \\
\hline Total & 149 & & & & .05 & .01 \\
\hline Coefficient (a) & 1 & & & & & \\
Regression (b/a) & 1 & 7353.043 & 7353.043 & $35.001^{* *}$ & 3.91 & 6.81 \\
Residual & 148 & 31091.791 & 210.080 & & & \\
\hline Deviation from Linearity & 55 & 12799.482 & 232.718 & $1.183^{\mathrm{ns}}$ & 1.45 & 1.69 \\
Error & 93 & 18292.308 & 196.691 & & & \\
\hline
\end{tabular}

$*^{*} \rho<.01 ;{ }^{\mathrm{ns}}:$ non significant

Based on above table, it showed that, regression model was significant with a regression equation of $\hat{Y}=77.960+$ $.442 \mathrm{X}_{1}$. Therefore, there was a positive relationship between citizenship behavior on managing the environment with job description which was very significant. Next a large correlation coefficient between job description with citizenship behavior on managing the environment was found, as shown in the following table 2.

Table 2:- Partial Correlation Coeff. $\left(\mathrm{r}_{\mathrm{y} 1.23}\right) ; * \mathrm{*}<.01$.

\begin{tabular}{|c|c|c|c|c|c|}
\hline $\begin{array}{c}\text { Sample } \\
(\mathrm{n})\end{array}$ & $\begin{array}{c}\text { Correlation } \\
\text { Coefficient (zero) }\end{array}$ & $\begin{array}{c}\text { Second order } \\
\text { correlation }\end{array}$ & $\mathrm{t}_{\text {cal }}$ & \multicolumn{2}{|c|}{$\mathrm{t}_{\text {table }}$} \\
\cline { 5 - 6 } & .437 & .246 & $5.91^{* * *}$ & .05 & .01 \\
\hline 150 & .437 & 2.61 \\
\hline
\end{tabular}

There was highly significant correlation between job description with citizenship behavior on managing the environment. The variation of citizenship behavior on managing the environmentwas determined by $6.1 \%$ of the job description variation through the regression model $\hat{Y}=77.960+.442 \mathrm{X}_{1}$.

The relationship between leader behavior with citizenship behavior on managing the environment could be seen in the regression equation which generates the direction of regression coefficients $b=.615$ and constants $=58.683$. To determine the degree of significance (level of significance). The $\mathrm{F}$ was subsequently tested, as shown in the following table 3 :

Table 3:-ANOVA Table for Regression Model of $\hat{\mathrm{Y}}=58.683+.615 \mathrm{x}_{2}$

\begin{tabular}{|l|c|c|c|c|c|c|}
\hline \multicolumn{1}{|c|}{$\begin{array}{c}\text { Source of } \\
\text { Variances }\end{array}$} & $\begin{array}{c}\text { Degrees of } \\
\text { Freedom (DF) }\end{array}$ & $\begin{array}{c}\text { Sum of } \\
\text { Square } \\
\text { (SS) }\end{array}$ & $\begin{array}{c}\text { Means } \\
\text { Square } \\
\text { (MS) }\end{array}$ & \multicolumn{2}{c|}{$\mathrm{F}_{\text {cal }}$} & \multicolumn{2}{c|}{$\mathrm{F}_{\text {table }}$} \\
\hline Total & 149 & & & & .05 & .01 \\
\hline Coefficient (a) & 1 & & & & & \\
Regression (b/a) & 1 & 9662.144 & 9662.144 & $49.68^{* *}$ & 3.91 & 6.81 \\
Residual & 148 & 28782.689 & 194.478 & & & \\
\hline $\begin{array}{l}\text { Deviation from Linearity } \\
\text { Error }\end{array}$ & 42 & 9168.540 & 218.299 & $1.18^{\text {ns }}$ & 1.49 & 1.76 \\
\hline
\end{tabular}

$* * \rho<.01 \quad{ }^{\mathrm{ns}}:$ non significant

Examined above table, it could be interpreted that regression equation was significant with a regression model $\hat{Y}=$ $58.683+.615 \mathrm{X}_{2}$. Therefore, there was a positive relationship between citizenship behavior on managing the environment with leader behavior which was very significant. Next a large correlation coefficient between leader behavior with citizenship behavior on managing the environment was found, as shown in the following table 4 . 
Table 4:-Partial Correlation $\left(\mathrm{r}_{\mathrm{y} 2.13}\right)$

\begin{tabular}{|c|c|c|c|c|c|}
\hline \multirow{2}{*}{$\begin{array}{l}\text { Sample } \\
\text { (n) }\end{array}$} & \multirow{2}{*}{$\begin{array}{c}\text { Correlation } \\
\text { Coefficient (zero) }\end{array}$} & \multirow{2}{*}{$\begin{array}{l}\text { Second order } \\
\text { correlation }\end{array}$} & \multirow[t]{2}{*}{$\mathrm{t}_{\mathrm{cal}}$} & \multicolumn{2}{|c|}{$\mathrm{t}_{\text {table }}$} \\
\hline & & & & .05 & .01 \\
\hline 150 & .501 & .373 & $7.05^{\text {*** }}$ & 1.97 & 2.61 \\
\hline
\end{tabular}

$* * \mathrm{p}<.01$

There was highly significant correlation between leader behavior with citizenship behavior on managing the environment. The variation of citizenship behavior on managing the environmentwas determined by $13.9 \%$ of the leader behavior variation through the regression model of $\hat{Y}=58.683+.615 \mathrm{X}_{2}$.

The relationship between personality with citizenship behavior on managing the environment could be seen in the regression equation which generates the direction of regression coefficients $b=.292$ and $a=107.109$.

Table 5:-ANOVA Table for Regression Model of $\hat{Y}=107.109+.292 X_{3}$

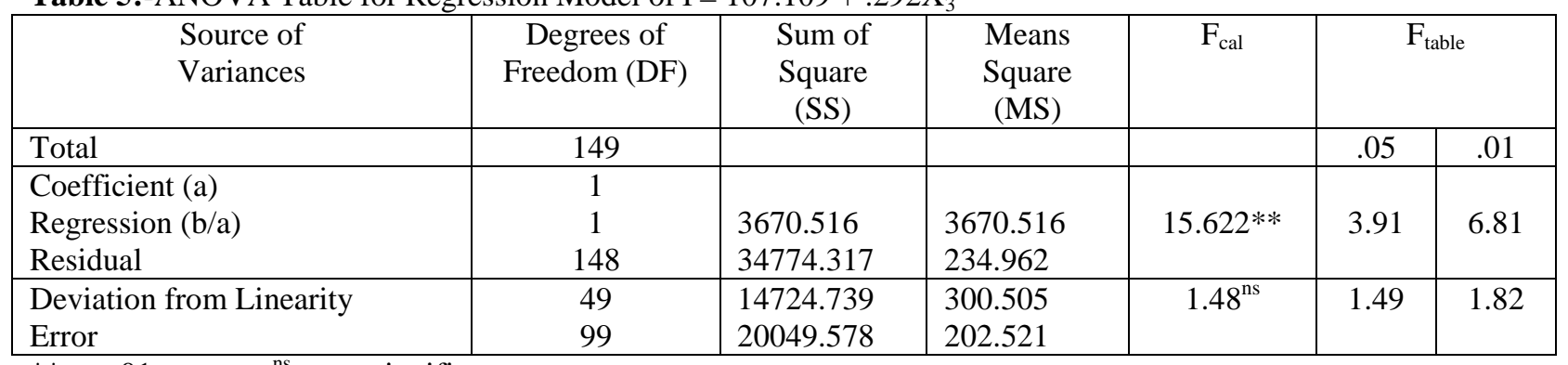

$* * \rho<.01 \quad{ }^{\mathrm{ns}}:$ non significant

Above table indicated that there was significantregression model of $\hat{Y}=107.109+.292 \mathrm{X}_{3}$. Therefore, there was a positive relationship between citizenship behavior on managing the environment with personality which was very significant. Correlation coefficient between personality with citizenship behavior on managing the environment was found, as shown in the following table 6.

Table 6:- Partial Correlation $\left(\mathrm{r}_{\mathrm{y} 3.12}\right)$

\begin{tabular}{|c|c|c|c|c|c|}
\hline \multirow{2}{*}{$\begin{array}{l}\text { Sample } \\
\text { (n) }\end{array}$} & \multirow{2}{*}{$\begin{array}{c}\text { Correlation } \\
\text { Coefficient (zero) }\end{array}$} & \multirow{2}{*}{$\begin{array}{l}\text { Second order } \\
\text { correlation }\end{array}$} & \multirow[t]{2}{*}{$\mathrm{t}_{\mathrm{cal}}$} & \multicolumn{2}{|c|}{$t_{\text {table }}$} \\
\hline & & & & .05 & .01 \\
\hline 150 & .309 & .184 & $3.95^{* *}$ & 1.97 & 2.61 \\
\hline
\end{tabular}

$* * \mathrm{p}<.01$

There is highly significant correlation between personality with citizenship behavior on managing the environment. The variation of citizenship behavior on managing the environmentwas determined by $3.4 \%$ of the personality variation through the regression model $\hat{\mathrm{Y}}=107.109+.292 \mathrm{X}_{3}$.

The shape of the relationship between job description, leader behavior, personality with citizenship behavior on managing the environment could be seen on regression equation which produced a directions of regression coefficient $=b_{1}=.237 ; b_{2}=.448 ; b_{3}=.152 ;$ and constant $=35.779$ (see table 7 ).

Table 7:-ANOVA Table for Multiple Regression of $\hat{Y}=35.779+.237 \mathrm{X}_{1}+.448 \mathrm{X}_{2}+.152 \mathrm{X}_{3}$

\begin{tabular}{|c|c|c|c|c|c|c|}
\hline $\begin{array}{l}\text { Source of } \\
\text { Variances }\end{array}$ & $\begin{array}{c}\text { Degrees of } \\
\text { Freedom (DF) }\end{array}$ & $\begin{array}{c}\text { Sum of } \\
\text { Square } \\
(\mathrm{SS})\end{array}$ & $\begin{array}{c}\text { Means } \\
\text { Square } \\
\text { (MS) }\end{array}$ & $\mathrm{F}_{\mathrm{cal}}$ & \multicolumn{2}{|c|}{$\mathrm{F}_{\text {table }}$} \\
\hline Total Direduct & 149 & & & & .05 & .01 \\
\hline $\begin{array}{l}\text { Regression } \\
\text { Residual }\end{array}$ & $\begin{array}{c}3 \\
146\end{array}$ & $\begin{array}{l}12886.763 \\
25558.071\end{array}$ & $\begin{array}{l}4295.588 \\
175.055\end{array}$ & $24.53 * *$ & 2.67 & 3.92 \\
\hline
\end{tabular}

$* * \rho<.01$

Based onabove table, regression equation model showed that it wassignificant with a regression model $\hat{\mathrm{Y}}=35.779+$ $.237 \mathrm{X}_{1}+.448 \mathrm{X}_{2}+.152 \mathrm{X}_{3}$. Therefore, there was a positive relationship between citizenship behavior on managing 
the environment with job description, leader behavior, and personality which was very significant. A large correlation coefficient between job description, leader behavior, and personality with citizenship behavior on managing the environment(see table 8).

Table 8:-Multiple Correlation $\left(\mathrm{R}_{\mathrm{y} 123}\right)$

\begin{tabular}{|c|c|c|c|c|c|}
\hline $\begin{array}{c}\text { Sample } \\
(\mathrm{n})\end{array}$ & $\begin{array}{c}\text { Multiple Correlation } \\
\text { Coefficient }\end{array}$ & $\begin{array}{c}\text { Multiple } \\
\text { Determination Coeff. }\end{array}$ & Fcal & \multicolumn{2}{|c|}{ Ftable } \\
\cline { 4 - 6 } & .579 & .335 & $24.55^{* *}$ & 2.67 & 3.92 \\
\hline 150 & & .05 & 2.67 & \\
\hline
\end{tabular}

$* * \mathrm{p}<.01$

It indicated that around $33.5 \%$ of the citizenship behavior on managing the environment variation determined all together by the variations of the job description, leader behavior, and personality through the linier regression model, as follows: $\hat{Y}=35.779+.237 \mathrm{X}_{1}+.448 \mathrm{X}_{2}+.152 \mathrm{X}_{3}$. Based on table above, the value of the correlation coefficient between job description, leader behavior, and personality with citizenship behavior on managing the environment of $\mathrm{ry}_{123}=.579$. The higher the job description, leader behavior, and personality, the more positive was citizenship behavior on managing the environment.

The first hypothesis proposed that job description was positively related to citizenship behavior on managing the environment. A positive relationship indicated by the regression model of $\hat{Y}=77.960+.442 X_{1}$ with $t$-cal $>t$ table and the strength of the relationship ryx $_{1}=.437$ with a coefficient of determination of $6.1 \%$. The success of citizenship behavior on managing the environment a company was determined by its job description of the company. The job description in this study includes the dimensions of work specialization, span of control, chain of command, formalization, delegation (centralization and decentralization) to preserve the environment.

The basic theoretical reference used in explaining citizenship behavior on managing the environment such as job description the theory Integrative Model of Organizational Behavior from Colquitt, et.al (2009: 34). In addition, in accordance with the results of research conducted by Mukherjee and Ghosh (2014: 1), that over the last few decades, India has socialized corporate social responsibility (CSR) in various companies. In the economic and social upheaval and from the tremendous pressure of environmentally conscious consumers, the Government, environmentalists, and Indian organizations are increasingly improving the CSR strategy by putting emphasis on corporate and employee responsibilities. The results show the differences in human behavior with CSR practices. Research suggests how organizations tend to be positive and wise to environmental management by meeting needs but without compromising the needs of future generations.

Moreover, according to Chen, et.al., (2015: 82), facing the situation of product or service demand and competition to gain customer trust, then the pro-environment company must be able to solve the environmental problems, it will have a positive ability in affecting the performance employees, and ultimately for the environmental performance of the company. From the results of the above explanation, then obtained a positive relationship between job description with citizenship behavior on managing the environment.

Another hypothesis test result depicted that the leader behavior was positive and highly significant with the citizenship behavior on managing the environment. The success of citizenship behavior on managing the environment of a company is determined by the leader behavior of a company. Leader behavior in this research includes the dimensions of helping, sportsmanship, loyalty, organizational compliance, individual initiative, civic virtue, and self-development. The basic theoretical reference used in describing citizenship behavior on managing the environment such as leader behavior using the umbrella theory of Responsible Behavioral Behavior toward the Environment that has been adapted by Blaikie\& Ward (1993) from Model Hinnes et.al., (1986/1987).

According to Robbins and Judge (2013: 368-371), leadership is the ability to influence a group of people in achieving a vision or set of goals. In the theory of leadership character (Trait theories of leadership), one's leadership is seen in one's quality and character. Whereas in behavior theories of leadership theory, subordinates see the leader from the aspect of initiating the plan (ie the extent to which the leader explains the plan and the role of the subordinate and attention (consideration), namely the extent to which leaders build friendships with staff to each other trust (mutual trust), attention to the ideas of subordinates (respect for employees). Based on other research, $66 \%$ of staff are motivated by the attention of the leaders. 
As an addition, Newstrom (2007: 26), in history, some leadership researchers emphasize the importance of situations in the leadership process, in which situations are not based on the person's traits or skills, but rather a situational perspective in handling a problem in times of economic crisis, social unrest, problems such as natural disasters and so forth. One attempt to include situational factors in leadership theory is the multiple influence model of Hunt and Osborn. Where in this model differentiated that microvariable (task factor) with makrovariabel (external environmental factors) in the situation in an organization or institution.

Research conducted by Olivier Boiral, Charles Baron and Olen Gunnlaugson (2014: 363-365), that the successful implementation of the practice environment (ie, implementation of sustainability policies, pollution prevention measures, industrial ecological promotion, environmental training programs) top manager. This is based on an institution or organization that cares about the environment around it is highly dependent on the extent to which leaders have commitment and leadership in positioning themselves as top managers in the implementation of management functions, so that it can improve the function of organizational structure. Based on the above explanation, an institution or organization that cares about the environment around it is very dependent on the extent to which leaders (leaders). Where leaders are committed and leadership in positioning themselves as top managers within a company supported by behavior in managing the environment. Based on the above explanation there is a very significant positive relationship between leader behavior and citizenship behavior on managing the environment.

The rest of other hypothesis verification revealed that personality was positive and highly significant with citizenship behavior on managing the environment. The success of citizenship behavior on managing the environment of a company was determined by employees personality. Big-five personality model consist of Conscientiousness, Agreeables, Neuroticism, Opennes and Extraversion. Bakker, Tim and Derks (2012: 1360-1361), several studies have revealed that positive personality in employees indicated good job performance as well, because the positive environmental impacts in the company facilitate the involvement of the personality work and the resulting resources.

It is important for employees to demonstrate proactive behavior and optimize their own work environment. Furthermore, research conducted by McCrae and Costa, Jr. (1987: 81), the results showed that the five factors of human personality in adults, showing a strong relationship between one another. These findings reinforce previous research data on a five-factor model in personality research. Based on the above explanation there is a positive and highlysignificant correlation between personality and citizenship behavior on managing the environment. Comparing to research conducted by Putrawan (2017), it supported this finding which people pro-ecological behavior could be best predicted by their personality, especially environmental personality.

The results of the fourth hypothesis test show that the job description, leader behavior, and personality are together positively and highly significant with citizenship behavior on managing the environment. The success of citizenship behavior on managing the environment is determined by the job description, leader behavior, and the personality of its employees. Research conducted by Terry Ransom-Flint (2006: 121), that the impact of integration of intervention implementation of the intention more effective to promote individual behavior. In this case, the implementation of a strong and weak intention also determines one's behavior. Bakker, Tims and Derks (2012: 1360-1361), that some studies have revealed positive personality in employees showing good job performance anyway. The positive corporate environmental impacts facilitate job engagement from personality outcomes. Therefore the management can affect the work of employees and resources generated. It is important for employees to demonstrate proactive behavior and optimize the work environment of employees.

Research conducted by Takashi Mino and Keisuke Hanaki (2013: 19-23), that the development of environmental leadership can holistically face the existing environmental problems. Environmental leaders promote the sustainability of environmental issues to protect the natural environment in decision-making and action processes. So it can be concluded that in this study the transformational-style leadership variables affect the environmental performance of the organization. Based on the above explanation there is a positive and very significant relationship between the job description, leader behavior, and personality together with the citizenship behavior on managing the environment.

The pure contribution of each variable is known by controlling other independent variables. The results of the analysis can show the rank of the relationship as shown in the following table 9: 
Table 9:-Second-Order Correlation among Variables

\begin{tabular}{|c|c|c|}
\hline Partial Corr. notation & Second-Order Corr. Coeff. & Strength in contribution \\
\hline $\mathrm{r}_{\mathrm{y} 1.23}$ & .246 & Second \\
\hline $\mathrm{r}_{\mathrm{y} 2.13}$ & .373 & First \\
\hline $\mathrm{r}_{\mathrm{y} 3.12}$ & .184 & Third \\
\hline
\end{tabular}

Based on the above table, the first relationship strength rank is behavior leader of .373; job description equal to .246; and the third personality of .184. These findings would be expected to add a treasure that enriches scientific knowledge, especially about citizenship behavior on managing the environment.

\section{Conclusion:-}

Based on these findings it could be concluded that when employees' citizenship behavior on managing the environment would be positively improved, then factors such as job description, leader behavior and personality could not be neglected. Therefore, these findings could be beneficial in contributing the theoretical basic if employees' citizenship behavior for managing the environment would be measured, by considering the role of leader behavior, job description and especially personality.

\section{References:-}

1. Bakker,Arnold B. Maria Tims and Daantje Derks. Proactive Personality and Job Performance: The Role of Job Crafting and Work Engagement. Journal of Human Relations, 2012.

2. Boiral, Olivier., Charles Baron and Olen Gunnlaugson. Environmental Leadership and Counsciousness Development: A Case Study Among Canadian SMEs. Journal Business Ethics,Springer, 2014.

3. Byars. L., Llloyddan Rue, Leslie W. Human Resource Management, 8 edition. MCGraw-Hill, Irwin, 2006.

4. Chen, Yang.,Guiyao Tang, Jiafe Jin, Jilin and Pascal Paile, "Linking Market Orientation and Environmental Performance:The Influence of Environmental Strategy, Employee's Environmental Involvement, Environmental Product Quality," Journal of Business Ethics, 2015.

5. Colquitt, Jason A., Jeffery A. Lepinedan Michael J. Wesson. Organizational Behavior Improving Performance in The Work Place. New York: McGraw-Hill, Inc., 2009.

6. Colquitt, Jason A., Jeffery A. Lepinedan Michael J. Wesson. Organizational Behavior: Improving Performance and Commitment in the Workplace. New York: McGraw Hill, 2011.

7. Ivancevich, John M. et al,.OrganizationalBehavior\& Management. New York: McGraw-Hill Education, 2011.

8. Luthans, Fred. OrganizationalBehaviorEleventh Edition. Singapore: McGraw-Hill International Edition, 2008.

9. McCrae, Robert R. dan Paul T. Costa, Jr,. Validation of the Five-Factor Model of Personality A cross Instrumens and Observers. National Institute on Aging and National Institudes of Health, Journal of Personality and Social Psychology, 1987.

10. Mino, Takashi and Keisuke Hanaki. Environmental Leadership Capacity Building in Higher Education Experience and Lessons from Asian Program for Incubation of Environmental Leaders. Springer: Tokyo, 2013.

11. Mukherjee, Raja dan IndranathGhosh, Going Green: The New Strategy for EnvironmentalSustainability and CSR in India. The International Journal of Business \& Management, Vol 2 Issue 2, February, 2014.

12. Newstrom, John W. OrganizationalBehavior. New York: McGraw-Hill, 2011.

13. Paile, Pascal., Yang Chen, Olivier Boiral and Jiafie Jin, The Impact of Human Resource Management on Environmental Performance: An Employee Level Study. Journal of Business Ethics, 2013.

14. Pervin, Lawrence A. and John P. Oliver, PersonalityTheory and Research USA: John Willey and Sons, Inc., 1997.

15. Putrawan, I Made, "PredictingResponsibleEnvironmentalBehevaior (REB) based on Personality, NEP and Naturalistic Intelligence," Advanced Science Letters, Vol. 23 (9), September, pp.5586-5593, 2017.

16. Ransom-Flint, Terry. Implementation Intentions, Personality, and ExerciseBehavior. The Ohio State University, 2006.

17. Rhodewalt, Frederick (Ed). Personality and Social Bahavior. New York: Taylor \& Francis Group, 2008.

18. Robbins, Stephen P. \& Timothy A. Judge. OrganizationalBehavior USA: Pearson, 2013.

19. Robertson, Jennifer L. and Julian Barling, "Greening Organization ThroughLeadersInfluence on Employees Pro-environmental Behaviors", Journal of Organizational Behavior, 2013.

20. Rothwell, William J. and H.C. Kazanas. The StrategicDevelopment of Talent: A FramWork for Using Talent to Support YourOrganizationalStrategy. Second Edition. USA: HRD Press, Inc., 2003.

21. Yukl, Gary. Leadership in Organizations. New Jersey: Pearson, 2010. 